\title{
Haematological and Antioxidant Properties of Alloxan-Induced Diabetes Rats Supplemented with Antioxidant Micronutrients
}

\author{
M.K. Dallatu ${ }^{1 *}$, P.O. Anaja ${ }^{2}$, L.S. Bilbis ${ }^{3}$, F.B.O. Mojiminiyi ${ }^{4}$, A. Mohammed $^{5}$ and Y. Tanko $^{5}$ \\ ${ }^{1}$ Department of Chemical Pathology, School of Medical Laboratory Sciences, ${ }^{3}$ Department of \\ Biochemistry, ${ }^{4}$ Department of Physiology, Usmanu Danfodiyo University, Sokoto, Nigeria. \\ ${ }^{2}$ Department of Chemical Pathology, Ahmadu Bello University Teaching Hospital, Zaria, Nigeria., \\ ${ }^{5}$ Department of Human Physiology, Faculty of Medicine, Ahmadu Bello University, Zaria, Nigeria. \\ [* Corresponding author: mkd12000@yahoo.com]
}

\begin{abstract}
Oxidative stress is elevated in patients with diabetes mellitus and oxidative modification of red cell membrane increases its fragility. Micronutrients with antioxidant effect protect structure and function of biological membranes. In the current study, manganese, copper and zinc, were supplemented in alloxan-induced diabetic rats for a period of 4 weeks. Haematological indices were determined by standard methods and results analyzed using InStat3 Statistical Software. Haemoglobin, packed cell volume, and red blood cell concentrations were $16.91 \pm 0.23 \mathrm{~g} / \mathrm{dl}, 50.0 \pm 1.11 \%$ and $5.63 \pm 0.32\left(10^{12} / \mathrm{L}\right)$ in controls $12.43 \pm 0.71 \mathrm{~g} / \mathrm{dl}, 36.42 \pm 1.38 \%$ and $4.58 \pm 0.23\left(10^{12} / \mathrm{L}\right)$ in treated unsupplemented group, and $13.84 \pm 0.43 \mathrm{~g} / \mathrm{dl}, 42.14 \pm 1.67 \%$ and $5.54 \pm 0.32\left(10^{12} / \mathrm{L}\right)$ in treated and supplemented groups respectively. Mean cell volume, mean cell haematocrit and mean cell haematocrit concentration values were $9.39 \pm 0.25 \mathrm{fl}, 3.15 \pm 0.12 \mathrm{pg}$ and $0.33 \pm 0.01 \mathrm{~g} / \mathrm{L}$ in controls, $8.18 \pm 0.46 \mathrm{fl}, 2.74 \pm 0.09 \mathrm{pg}$ and $0.34 \pm 0.62 \mathrm{~g} / \mathrm{L}$ in the treated unsupplemented group, and $7.99 \pm 0.65 \mathrm{fl}, 2.57 \pm 0.18 \mathrm{pg}$ and $0.32 \pm 0.01 \mathrm{~g} / \mathrm{L}$ in the treated and supplemented group respectively. Activities of superoxide dismutase, glutathione peroxidase and catalase were $2.00 \pm 0.17 \mathrm{U} / \mathrm{mg}$ protein, $46.43 \pm 4.25 \mathrm{U} / \mathrm{mg}$ protein and $59.86 \pm 1.08 \mathrm{U} / \mathrm{mg}$ protein in the controls, $1.67 \pm 0.22 \mathrm{U} / \mathrm{mg}$ protein, $36.88 \pm 3.91 \mathrm{U} / \mathrm{mg}$ protein and $39.86 \pm 3.03 \mathrm{U} / \mathrm{mg}$ protein in the unsupplemented group and $1.61 \pm 0.18 \mathrm{U} / \mathrm{mg}$ protein, $44.86 \pm 1.82 \mathrm{U} / \mathrm{mg}$ protein and $57.14 \pm 2.48 \mathrm{U} / \mathrm{mg}$ protein in the supplemented group respectively. The concentration of malondialdehyde was $1.83 \pm 0.16 \mathrm{nmol} / \mathrm{ml}$ in controls, $2.37 \pm 0.19 \mathrm{nmol} / \mathrm{ml}$ in supplemented group and $1.91 \pm 1.14 \mathrm{nmol} / \mathrm{ml}$ in the supplemented group. It may be concluded from the present study that antioxidant micronutrient improve some haematological and antioxidant indices and reduce lipid peroxidation in alloxan-induced diabetic rats.
\end{abstract}

Keywords: diabetes, haematological indices, micronutrients, lipid peroxidation.

\section{INTRODUCTION}

Trace elements play important role in the structure and function of biological membrane (Bettger and O'Dell, 1993), and oxidative modifications of the membrane increase fragility of red blood cells (Wagner, 1988). This suggested an important role of oxidative damage in the impaired functions of erythrocyte. Oxidative attack on red blood cells (RBC) may lead to haemolysis and consequent anaemia and deplete endogenous antioxidant reserves in the blood (Umar et al., 2007). According to Schwartz et al., (1991) many studies have indicated that the rheological properties of diabetic erythrocytes are abnormal, and that glucose derived oxidative stress may be responsible for osmotic fragility and altered deformability of red blood cells due to membrane lipid peroxidation.

The defence of cell membranes against oxidative damage caused by activated oxygen is a complex process that involves a battery of interrelated protective agencies. These include different antioxidant enzymes (AOE) such as copper, zinc-superoxide dismutase $(\mathrm{Cu}, \mathrm{Zn}$ SOD) primarily in the cytoplasm, whereas manganese superoxide dismutase (MnSOD) is located primarily in the mitochondria. Both catalyse the dismutation of superoxide $\left(\mathrm{O}^{2-}\right)$ to $\mathrm{H}_{2} \mathrm{O}_{2}$, which in turn, is converted to $\mathrm{H}_{2} \mathrm{O}$ in the 
peroxisomes by AOE catalase (CAT) and in cytoplasm by glutathione peroxidase (GPX) (Shull et al., 1991). Nutrients with antioxidant effect include minerals selenium, copper, zinc and manganese, and vitamins E, C and probably $\mathrm{A}$ as well as $\beta$-carotene. These micronutrients which have come to be regarded as antioxidant nutrients lie functionally at the heart of this protective mechanism (Diplock, 1991).

The possibility of a relationship in human subjects between diet and chronic or acute diseases has been a major preoccupation of nutrition and medical scientists throughout history. Many nutritional organizations have attempted to evaluate relationships of particular dietary factor and particular disease, and various constituents of food have been seen both as preventive and causative factors in the etiogenesis of diseases (Diplock, 1991).

Diabetes state is a proxidant state, with subsequent stressful state, followed by oxidative damages, and protection is provided by enzymatic antioxidant defences or by freeradical scavenging micronutrients (Marian, et al., 2006).

The present study was carried out to investigate the effect of supplementing antioxidant micronutrients on some components of the blood. Furthermore, indicators of oxidative damage, malondialdehyde (MDA) and activities of antioxidant defence enzymes; superoxide dismutase (EC 1.15.1.1), catalase (EC 1.11.1.6) and glutathione peroxidase (EC 1.11.1.9) were also determined.

\section{MATERIALS AND METHODS}

Experimental Animals: Male albino wistar rats $(120-180 \mathrm{~g})$ were purchased from Animal House, Faculty of Pharmaceutical Sciences, Ahmadu Bello University, Zaria. The animals were housed under similar conditions in standard cages at $25 \pm 2^{\circ} \mathrm{C}$, with 12 -hr light/dark cycle in the Animal House, Department of Human Physiology, Ahmadu Bello University, Zaria. The animals were maintained on poultry feed (Vital Feeds, Jos) ad libitum.

Chemicals: All the reagents used for the study were of analytical grade. Alloxan was purchased from Sigma Aldrich Chemical Co. (U.K), kits for the assay of MDA, CAT, SOD and GPX were purchased from North-West Life Science Specialties, Vancouver, Canada.

Induction of Diabetes: Experimental diabetes was induced by a single intraperitonial injection of freshly dissolved Alloxan ( $150 \mathrm{mg} / \mathrm{kg} \mathrm{b.w})$ in normal saline maintained at $37^{\circ} \mathrm{C}$, to rats fasted for 12 hours. Control rats received a similar volume of normal saline alone. After 72 hours of alloxan injection, the animals were fasted overnight and their fasting blood glucose were estimated using a commercial glucose kit. Only rats that had fasting blood glucose level of 126 $\mathrm{mg} / \mathrm{dl}(>7.00 \mathrm{mmol} / \mathrm{l})$ and partial destruction of pancreas tested with positive response to metformin were included in the study (Dulin and Soret, 1978).

Experimental Design: The rats were divided into 3 groups of 7 rats each:- Group i: Normal Control; Group ii Diabetic + metformin (250 $\mathrm{mg} / \mathrm{kg})$; Group iii Diabetic + metformin $(250$ $\mathrm{mg} / \mathrm{kg})+$ copper $(2 \mathrm{mg} / \mathrm{kg})+$ manganese $(10$ $\mathrm{mg} / \mathrm{kg})+$ zinc $(15 \mathrm{mg} / \mathrm{kg})$. The supplementation lasted for one month and after the last day; the animals were fasted overnight and anaesthesized by dropping each in a transparent plastic jar saturated with chloroform vapour. Blood sample was collected through cardiac puncture and divided into plain and EDTA-containing centrifuge tubes. Humane procedure was adopted throughout the experiment.

Measurement of Biochemical Analytes: Blood glucose concentration was assayed using glucose oxidase method (Trinder, 1969). MDA level was assayed based on MDA reaction with thiobarbituric acid (TBA) and activities expressed as $\mathrm{nmol} / \mathrm{ml}$ (Botsoglou, 1994). CAT activity was measured using $\mathrm{H}_{2} \mathrm{O}_{2}$ as substrate, and the unit expressed as U/mg protein (Beers and Sizer, 1952). GPX activity was measured by NADPH oxidation, and the activities expressed as U/mg protein (Paglia and Valentine, 1967). SOD activity was assayed using the autooxidation of hematoxylin and the unit of activity expressed as $\mathrm{U} / \mathrm{mg}$ protein (Martin et al., 1987).

Red Blood Cells (RBC) were determined by visual counting method, using an improved neubaur counting chamber. Haemoglobin $(\mathrm{Hb})$ was measured colorimetrically using cynamethaemoglobin method. Packed Cell Volume (PCV) was determined by micro 
haematocrit technique, and red cell indices (absolute values) were calculated from these data (Baker and Silverton, 2001).

Statistical Analysis: All data were expressed as the mean \pm Standard Error of Mean (S.E.M). Data was analyzed using analysis of various (ANOVA), InStat3 Software. Differences in mean were considered to be significant when $\mathrm{p}<$ 0.05 .

\section{RESULTS}

Results of the present study are presented in Tables 1 and 2. Red Blood Cells (RBC) concentration were $5.63 \pm 0.32\left(\mathrm{x} 10^{12} / \mathrm{L}\right)$ in controls, $4.58 \pm 0.23\left(\mathrm{x} \quad 10^{12} / \mathrm{L}\right)$ in treated unsupplemented group, and 5.54 $\pm 0.32\left(\times 10^{12} / \mathrm{L}\right)$ in the treated and supplemented group. There was no statistically significant difference between the groups $(\mathrm{p}>0.05)$. Haemoglobin $(\mathrm{Hb})$ concentration were $16.91 \pm 0.23 \quad(\mathrm{~g} / \mathrm{dl})$ in controls, $\quad 12.43 \pm 0.71 \quad(\mathrm{~g} / \mathrm{dl}) \quad$ in treated unsupplemented group, and $13.84 \pm 0.43(\mathrm{~g} / \mathrm{dl})$ in the treated and supplemented group. There were statistically significant differences between controls and treated unsupplemented group $(\mathrm{p}<0.001)$, and between controls and treated supplemented group $(\mathrm{p}<0.01)$. PCV were $50.0 \pm 1.11 \%$ in controls, $36.43 \pm 1.38 \%$ in treated not supplemented and $42.14 \pm 1.67 \%$ in treated supplemented group. There were statistically significant differences between controls and treated unsupplemented $(\mathrm{p}<0.001)$ and between controls and treated supplemented group $(\mathrm{p}<0.01)$. The mean corpuscular haemoglobin $(\mathrm{MCH})$ concentrations were $3.15 \pm 0.11 \mathrm{pg}$ in controls, $2.74 \pm 0.09 \mathrm{pg}$ in treated unsupplemented, and $2.57 \pm 0.18 \mathrm{pg}$ in treated supplemented group. There was statistically significant difference between controls and treated supplemented group $(\mathrm{p}<0.05)$, but the difference between controls and treated unsupplemented was not significant ( $\mathrm{p}>0.05)$.

Table 1 Blood Concentration of Some Haematological Indices in Alloxan Induced Diabetic Rats Supplementated with Antioxidant Micronutrients

\begin{tabular}{|c|c|c|c|c|c|c|}
\hline Group & $\begin{array}{c}\mathrm{RBC} \\
\left(\times 10^{12} / \mathrm{L}\right)\end{array}$ & $\begin{array}{c}\mathbf{H b} \\
(\mathrm{g} / \mathrm{dl})\end{array}$ & $\begin{array}{l}\text { PCV } \\
(\%)\end{array}$ & $\begin{array}{c}\text { MCV } \\
\text { (fl) }\end{array}$ & $\begin{array}{c}\mathrm{MCH} \\
\text { (pg) }\end{array}$ & $\begin{array}{c}\text { MCHC } \\
(\mathrm{g} / \mathrm{L})\end{array}$ \\
\hline Controls & $5.63 \pm 0.32$ & $16.91 \pm 0.23$ & $50.00 \pm 1.11$ & $9.39 \pm 0.25$ & $3.15 \pm 0.11$ & $0.33 \pm 0.01$ \\
\hline Treated & $4.58 \pm 0.23$ & $12.43 \pm 0.71 * *$ & $36.43 \pm 1.38 * *$ & $8.18 \pm 0.46$ & $2.74 \pm 0.09$ & $0.34 \pm 0.02$ \\
\hline $\begin{array}{l}\text { Unsupplemented } \\
\text { Treated and } \\
\text { Supplemented }\end{array}$ & $5.54 \pm 0.32$ & $13.84 \pm 0.43 *$ & $13.84 \pm 0.43 *$ & $7.99 \pm 0.65$ & $2.57 \pm 0.18 *$ & $0.32 \pm 0.01 *$ \\
\hline
\end{tabular}

The mean corpuscular volume (MCV) levels were $9.39 \pm 0.25 \mathrm{fl}$ in controls $8.18 \pm 0.46 \mathrm{fl}$ in treated unsupplemented group, and $7.99 \pm 0.65 \mathrm{fl}$ in treated supplemented group. There was no statistically significant difference between controls and either of the groups ( $p>0.05)$. The mean corpuscular haemoglobin concentration (MCHC) were $0.33 \pm 0.01 \mathrm{~g} / \mathrm{L}$ in controls, $0.34 \pm 0.02 \mathrm{~g} / \mathrm{L}$ in treated unsupplemented group, and $0.32 \pm 0.01 \mathrm{~g} / \mathrm{L}$ in treated and supplemented group. There was no statistically significant difference between controls and the other groups $(\mathrm{p}<0.05)$.

Mean serum concentration of malondialdehyde (MDA) was $1.83 \pm 0.16 \mathrm{nmol} / \mathrm{ml}$ in the control group, diabetic treated not supplemented had a concentration of $2.39 \pm 0.15 \mathrm{nmol} / \mathrm{ml}$, while in the diabetic treated and supplemented, a concentration of $1.91 \pm 0.14 \mathrm{nmol} / \mathrm{ml}$ was recorded. The difference between the controls and diabetic treated but not supplemented was statistically significant $(\mathrm{p}<0.05)$, while the difference between the controls and diabetics treated and supplemented was not significant $(p>0.05)$. Mean serum activities of superoxide dismutase (SOD) were $2.0 \pm 0.17 \mathrm{U} / \mathrm{mg}$ proteins in the controls, $1.61 \pm 0.18 \mathrm{U} / \mathrm{mg}$ protein in the diabetic treated not supplemented, and $1.69 \pm$ $0.22 \mathrm{U} / \mathrm{mg}$ protein in the diabetic treated and supplemented group. There was however, no statistically significant difference $(\mathrm{p}>0.05)$ between the controls and the two classes of the 
diabetics. The mean serum activities of glutathione peroxidase (GPX) were $46.43 \pm 3.25$ $\mathrm{U} / \mathrm{mg}$ protein in the controls, $36.86 \pm 3.91 \mathrm{U} / \mathrm{mg}$ protein in the diabetic treated not supplemented and $44.86 \pm 1.82 \mathrm{U} / \mathrm{mg}$ protein in the diabetic treated and supplemented group. There was statistically significant difference between the control and unsupplemented groups $(\mathrm{p}<0.05)$, but the different between control and supplemented group was not significant $(\mathrm{p}>0.05)$.

Table 2: Serum Antioxidants in Alloxan Induced-Diabetic Rats Supplemented with Antioxidants Micronutrients.

\begin{tabular}{lllll}
\hline \multicolumn{1}{c}{ Group } & \multicolumn{1}{c}{$\begin{array}{c}\text { MDA } \\
(\mathrm{nmol} / \mathrm{ml})\end{array}$} & $\begin{array}{c}\text { SOD } \\
(\mathrm{U} / \mathrm{mg} \text { Prot. })\end{array}$ & $\begin{array}{c}\text { GPX } \\
(\text { U/mg prot. })\end{array}$ & $\begin{array}{c}\text { CAT } \\
(\text { U/mg Prot. })\end{array}$ \\
\hline Controls & $1.83 \pm 0.16$ & $2.0 \pm 0.17$ & $46.43 \pm 4.25$ & $59.86 \pm 1.08$ \\
Treated Unsupplemented & $2.39 \pm 0.15^{* *}$ & $1.61 \pm 0.18$ & $36.86 \pm 3.91 *$ & $39.86 \pm 3.03^{*}$ \\
Treated and Supplemented & $1.91 \pm 0.14$ & $1.67 \pm 0.22$ & $44.86 \pm 1.82$ & $57.14 \pm 2.48$ \\
\hline
\end{tabular}

Values are mean \pm Standard Error of Mean, ** = Significantly different from control, * = Significantly different from diabetic treated only $(p<0.01)$ using analysis of variance InStat3 Software.

The mean serum activities of catalase (CAT) were $59.86 \pm 1.08 \mathrm{U} / \mathrm{mg}$ protein in the controls, $39.86 \pm 3.04 \mathrm{U} / \mathrm{mg}$ protein in the diabetic treated not supplemented, and $57.14 \pm 2.48 \mathrm{U} / \mathrm{mg}$ protein in the diabetic treated and supplemented. There was statistically significant difference between the controls and the unsupplemented groups $(\mathrm{p}<0.05)$.

\section{DISCUSSION}

Under normal conditions of oxygen transport, reduced haemoglobin forms a reversible covalent compound with oxygen. However, there is 0.5 to $2 \%$ true oxidation of the iron from the ferrous to the ferric state. This form of haemoglobin is incapable of oxygen transport so that there is a decrease in the oxygen-carrying power of the blood, shift of the oxygen dissociation curve of the haemoglobin to the left, so that it gives up oxygen to the tissues less effectively than normal (Thompson, 1980).

In patients with diabetes mellitus, there is an increase in free radical generation, decreased antioxidant defences, and oxidative modifications of the membrane increase fragility of red blood cells, which led to anaemia and consequent depletion of endogenous antioxidant reserves (Umar et al., 2007).

As defence mechanisms, red blood cells contain a lot of antioxidant enzyme, $\mathrm{Cu}, \mathrm{Zn}-\mathrm{SOD}$, which keeps the erythrocyte levels of superoxide in check (Johnson et al., 2005). Additionally, glutathione and vitamin $\mathrm{C}$ are also reported to confer antioxidant defence on red blood cells membranes (Thompson, 1980).

In the current study, the observation that supplementation with antioxidant micronutrients may lead to increase quality of certain blood constituent was confirmed. There was significant improvement in the concentration of PCV $(\mathrm{p}<0.01)$ and non-significant improvement in the concentration of circulating $\mathrm{RBC}$ and $\mathrm{Hb}$ ( $p \geq 0.05)$ in the supplemented group when compared with the unsupplemented. There was also a significant improvement in some absolute values such as, $\mathrm{MCH}$ and non-significant improvement in some, like MCV and MCHC in the supplemented group, when compared to unsupplemented group. This is in agreement with the finding of Umar et al., (2007), who reported a decreased anaemia, improved renal and hepatic functions in trypanosome infected rats, supplemented with antioxidant micronutrients, and concluded that, oxidative attack on RBC may lead to heamolysis and consequent anaemia and deplete endogenous antioxidant reserves. According to Clemens and Waller (1987), membrane of RBC contains about $44 \%$ lipid, $49 \%$ protein and the rest is carbohydrate Peroxidative damage to the membrane causes morphological changes, increased membrane rigidity with consequent deformability, lipid peroxidation and damage to the membrane proteins and lipids.

Diabetic rats treated but unsupplemented with antioxidant micronutrients had a significantly $(\mathrm{p}<0.05)$ higher concentration of malondialdehyde (MDA) than controls. MDA 
can react and damage DNA bases. It is reported to be mutagenic in bacterial and mammalian cells and carcinogenic in rats (Valko et al., 2007). Our findings are similar with those of Bapat (2005) who reported that potentials for lipid peroxidation were lower in streptozocin induced diabetic rats supplemented with an Indian spices, believed to contain antioxidant micronutrients.

It was also shown in the present study, that supplementation with antioxidant micronutrients possesses the ability to inhibit oxidative processes through a significant increase in the serum activities of CAT and GPX, a significant decrease in the serum concentration of MDA and non-significant increase in the serum activities of SOD. This is in agreement with the finding of Holecek et al., (1995) who reported on increased activities of GPX and CAT, decreased concentration of MDA when he supplemented his diabetic subjects with antioxidant vitamins and minerals. SOD dismutate superoxide radicals $\left(\mathrm{O}^{2-}\right)$ to produce hydrogen peroxide $\left(\mathrm{H}_{2} \mathrm{O}_{2}\right)$. The $\mathrm{H}_{2} \mathrm{O}_{2}$ so produced are acted upon by glutathione peroxidase and catalase. The synergistic effect of these enzymes might be responsible for the observed antioxidant effect.

In conclusion, supplementation with antioxidant micronutrients may cause increase activities of some antioxidant enzymes, decreased concentration of some oxidative markers and improves the concentration of some blood indices in alloxan-induced diabetic rats. We recommend further research in this area, for possible consideration of micronutrients supplementation in the routine treatment of patients with diabetes mellitus.

\section{REFERENCES}

Baker, F.J; Silverton, R.E and Pallister, C.J. (2001). The Full Blood Count in: Baker and Silverton's Introduction to Medical Laboratory Technology ( $7^{\text {th }}$ ed.) Bountry Press Ltd, London NWI 3BH.

Bapat, M.M (2005). Free Radical Damage, Diabetes Mellitus and Dietary Antioxidant. S.F.R.R International Conference. Bangalore, India.

Beers, R.F. Jr. and Sizer, I.W. (1952). Spectrophotometric Method for Measuring the Breakdown of Hydrogen Peroxidase by Catalase. J. Biol. Chem. 195: 133-140.

Bettger, W.J; and O'Dell, B.L; (1993). Physiological Role of Zinc in the Plasma Membrane of Mammalian Cells. J. Nutr. Biochem; 4: 194-207.

Botsoglou, N.A. (1994). Lapid, Sensitive and Specific Thiobarbituric Acid Method for Measuring Lipid Peroxidation in Animal Tissue, Food and Feed Type Sample. J. Agric. Food Chem. 42: 1931-1937.

Clemens, M.R. and Waller, H.D (1987). Lipid Peroxidation in Erythrocytes. Chem. Phys. Lipid. 45: 251-54.

Diplock, A.T. (1991). Antioxidant Nutrients and Diseases Prevention: An Overview, Am. J. Clin. Nutr; 53: 1895-1935.

Dulin, W.E and Soret, M.G. (1978). Chemically and Hormonally Induced Diabetes. In Volk, B.W; Wellman, K.E. (eds) The Diabetic Pancreas. Plenum Press New York, pp. 425-437.

Holeckek, V., Racek, J. and Jerabek, Z. (1995). Administration of Multivitamins Combinations and Trace Elements in Diabetes. Caslek Cask, 134, 3: 80-83.

Johnson, R.M; Goyette, G. Jr.; Ravindranath, Y. and Ho, Y.S. (2005) Haemoglobin Oxidation and regulation of Endogenous $\mathrm{H}_{2} \mathrm{O}_{2}$ Levels in Erythrocytes. Free Rad. Biol. Med. 39: 1407-17

Marian, V; Dieter, L. and Jan Mancol (2006). Free Radicals and Antioxidant in Normal Physiological Function and Human Diseases. Int. I. Biochem. Cell. Biol. 39:4484.

Martin, J.P Jr., Dailey, M., and Sugarman, E. (1987). Negative and Positive Assays of Super Oxide Dismutase Based on Hematoxylin Autoxidation. Arch. Biochem. Biophys. 255:329-336.

Paglia, D.E. and Valentine, W.N. (1967). Studies on the Quantitative and Qualitative Characterization of Erythrocyte Glutathione Peroxidase. J. Lab. Med. 70: 158-169.

Schwartz R.B; Hadsen, J.W; Ribicki, A.C; Nagel, R.L. (1991). Oxidation of Spectrin and Deformability Defects in Diabetic Erythrocytes. Diabetes. 40: 701-8.

Shull, S; Heintz, H.H; Periasamy, M; Manohar, M (1991). Differential Regulation of 
Antioxidant Enzymes in Response to Oxidants. The Journal of Biological Chemistry. 226: 24398-24403

Trinder, P. (1969). Annals of Clinical Biochemistry: 6:24: Quoted in Cheesbrough, M. (1992) Medical Laboratory Manual for Tropical Countries. Vol. 1 ( $2^{\text {nd }}$ Edition). ELBS, Cambridge. 527-545.

Thompson, R.B. (1980). The Leucocytes in: A Short Textbook of Haematology. Pp. 1-25 Pitman Medical Limited, 57, High Street, Tunbridge, Wells Kent.

Umar, I.A; Oguyi, E; Okodaso, D; Kimeng, E (2007). Amelioration of Anaemia and
Organ Damage by Combined Intraperitoneal Administration of Vitamin $\mathrm{A}$ and $\mathrm{C}$ to Trypanosoma Brucei BruceiInfected Rats. African Journal of Biotechnology Vol. 6(18): 2033-2086.

Valko, M; Laibfritz, D; Mencol, J. (2007). Free Radical and Antioxidants in Normal Physiological Functions and Human Diseases. Int. J. Bio. Chem. Cell Bio. 39: 44-84.

Wagner, G.M; Lubin, B.H; and Chiu, D.T.Y. (1988), Oxidative Damage to Red Blood Cells, in Cellular Antioxidant Defence Mechanism (Chow,c.K ed.) 1: 188-195. CRC Press Inc; Boca Ratn, Florida. 